\title{
Development of West Greenlandic Markets for Country Foods Since the 18th Century
}

\author{
OLE MARQUARDT ${ }^{1}$ and RICHARD A. CAULFIELD ${ }^{2}$
}

(Received 15 March 1995; accepted in revised form 6 November 1995)

\begin{abstract}
Local markets for country foods have a history in West Greenland dating back to the early 18 th century. After Danish colonization in 1721, Greenlanders gradually began selling these foods (West Greenlandic: kalaalimerngit), which included seal, whale, caribou, fish, and birds - first to the Danes and later to other Greenlandic Inuit. This trade was a significant transformation of pre-contact Inuit exchange practices. In the 18th and early 19th centuries, the trade was largely between Greenlandic hunters and Danes employed by the colonial trade or by the church. Later in the 19th century, these institutions employed increasing numbers of indigenous Greenlanders. Economic specialization gradually became more pronounced within Greenlandic society, and cash became more prominent in local economies. Greenlandic hunters increasingly sold country foods to other Greenlanders earning wages. These practices continue today, with hunters regularly selling country foods in many towns at the local kalaalimineerniarfik (literally, "place where Greenlandic foods are sold"), to institutions such as schools or senior citizens' homes, and in larger stores. Today, Greenland's Home Rule government is promoting local country food markets as one strategy for sustainable development. The goals are to promote the use of nutritious and culturally valued foods on a sustainable basis and to provide economic opportunities for local hunters, particularly in outlying settlements. The history of Greenland's system for marketing country foods highlights some issues that may influence the contribution of country foods to sustainable community development in the Arctic.
\end{abstract}

Key words: West Greenland, Inuit, country foods, sustainable development, mixed economy, subsistence, commoditization, kalaalimerngit

RÉSUMÉ. L'existence d'un marché régional des denrées tirées de la nature dans le Groenland occidental est attesté depuis le début du XVIII ${ }^{\mathrm{e}}$ siècle. Après la colonisation danoise en 1721, les Groenlandais ont commencé à vendre graduellement ces produits alimentaires (kalaalimerngit, en Groenlandais occidental) — qui incluent phoque, baleine, renne, poisson et oiseaux — d'abord aux Danois, puis à d'autres Inuit du Groenland. Ce commerce marquait un changement important dans les pratiques d'échange préeuropéennes des Inuit. Aux XVIII ${ }^{\mathrm{e}}$ et XIX ${ }^{\mathrm{e}}$ siècles, le commerce avait cours surtout entre chasseurs groenlandais et Danois travaillant pour l'église ou le commerce avec les colonies. Au cours du XIX ${ }^{\mathrm{e}}$ siècle, ces institutions employèrent un nombre croissant d'autochtones groenlandais. La spécialisation économique devint graduellement plus prononcée au sein de la société groenlandaise, et l'argent plus dominant dans l'économie régionale. Les chasseurs groenlandais vendirent de plus en plus de denrées tirées de la nature à d'autres Groenlandais qui gagnaient un salaire. Ces pratiques continuent aujourd'hui, les chasseurs vendant régulièrement ces denrées dans de nombreuses agglomérations, au kalaalimineerniarfik (littéralement «place où est vendue la nourriture groenlandaise»), à des institutions comme écoles ou foyers pour personnes âgées, et dans des magasins plus grands. Aujourd'hui, le gouvernement autonome du Groenland favorise l'existence des marchés où sont vendues ces denrées locales tirées de la nature, comme une des stratégies de développement durable. Les buts sont de promouvoir l'utilisation, sur une base durable, d'aliments nutritifs et valorisés au plan culturel, ainsi que d'offrir aux chasseurs locaux des ouvertures économiques, en particulier dans les habitats éloignés. L'histoire du système groenlandais de mise en marché des denrées tirées de la nature souligne certains des enjeux qui peuvent influencer la contribution de ces denrées au développement durable des collectivités dans l'Arctique.

Mots clés: Groenland occidental, Inuit, denrées tirées de la nature, développement durable, économie mixte, subsistance, vente de denrées, kalaalimerngit

Traduit pour la revue Arctic par Nésida Loyer.

\section{INTRODUCTION}

Foraging societies have long exchanged and bartered country foods and goods with others (Leacock and Lee, 1982; Headland and Reid, 1989). In the circumpolar North, Inuit societies were not isolated prior to European contact, but engaged in trade and barter to varying degrees over great distances (Damas, 1984; Gulløv, 1985; Burch, 1988; Wenzel, 1991). Among other items, Inuit traded iron, soapstone, baleen, and flint. Trading often took place seasonally in well-known locations convenient to renewable resource harvesting. These trade gatherings were often impressive social events, as well,

\footnotetext{
${ }^{1}$ Ilisimatusarfik (University of Greenland), P.O. Box 1061, DK-3900 Nuuk, Greenland

${ }^{2}$ Department of Rural Development, University of Alaska Fairbanks, P.O. Box 756500, Fairbanks, Alaska 99775-6500, U.S.A.

(C) The Arctic Institute of North America
} 
where young people found spouses, distant family members were temporarily reunited, and people from remote settlements shared news and accounts of the year's activities (Rosing, 1984).

Yet contact with Euro-American culture dramatically transformed many elements of Inuit societies, including trade and bartering practices. Growing interaction with Europeans and Americans led to expanded trade and commercialization of renewable resources (Usher, 1986, 1987; Duerden, 1992). In the early contact period, Inuit economic strategies continued to be based on domestic production, and expanded trade was not generally perceived as a challenge to cultural values. Over time, however, expanding reliance on external markets led to growing dependency and vulnerability to fluctuating prices for locally produced goods.

Today, cash associated with trade is a significant component of mixed subsistence-cash economies in Inuit communities (Møller and Dybbroe, 1978; Wolfe and Ellanna, 1983; Langdon, 1986, 1991; Smith and Wright, 1989; Reeves, 1992; Reeves and Heide-Jørgensen, 1995). These economies typically have a community-wide seasonal round of harvest activities; high levels of renewable resource harvesting; a domestic mode of production; extensive noncommercial networks for sharing, distribution, and exchange; long-standing systems of land use and occupancy; and an integration of cash and subsistence sectors in a mixed economy (Wolfe and Ellanna, 1983; for Greenlandic examples, see also Caulfield, 1991).

Relationships between subsistence, cash, and commoditization have long interested social scientists. Early research postulated that expansion of trade and introduction of cash would almost inevitably lead to the breakdown of social relations in kin-based societies (Leacock and Lee, 1982). However, in a recent article about cash and commoditization, Peterson and Matsuyama (1991:67) note that:

\begin{abstract}
although cash and commoditization have been widely seen as inimical to the social relations taken to characterize small scale communities based on mechanical solidarity, setting off a one way process leading to destruction and replacement of indigenous practices and beliefs by those of the encapsulating society, it is increasingly clear that there is no single set of consequences.
\end{abstract}

Consistent with this, Usher (1986) points out that in the North, the convenient distinction between domestic and commercial production is becoming more complex. He sees two trends in this relationship in Inuit communities: 1) a rise in "commercial" characteristics of production and exchange; and 2) growing consumption of country foods by nonlocal people, including nonindigenous people in some areas. In Greenland, Dahl (1989) makes an even stronger assertion, arguing that distinctions between subsistence and cash-based economic sectors are artificial and meaningless. In his view, the two sectors are thoroughly intertwined.

Langdon's (1991) observations from Yup'ik Eskimo communities in southwestern Alaska mirror these findings, and suggest that cash and subsistence sectors can complement one another. According to his research, this can occur when human population densities are low relative to natural resources; resources are in adequate supply and not degraded; external demands for resources are limited; demands of the commercial sector are within the capabilities of local people; indigenous land and sea tenure systems are sustained; local production is not appropriated by taxation; production units remain kin-based; and cash is not fetishized.

We apply Langdon's framework for analyzing changing relationships between subsistence, cash, and commoditization to the situation in West Greenland by exploring the historical development and contemporary significance of local markets for country foods. In the West Greenlandic Inuit language (Kalaallisut), these foods are referred to as kalaalimerngit, or literally "Greenlanders' foods." These are distinguished from European (primarily Danish) foods, which are known as qallunaamerngit. Since Danish colonization began in 1721, Greenlanders have sold country foods to non-Greenlanders (primarily Danes) living in local communities. In the latter part of the 19th century, hunters increasingly sold country foods to other Greenlanders who worked for wages. In recent decades, these transactions have often taken place at a kalaalimineerniarfik (literally, "the place where Greenlandic foods are sold"; in Danish, "brædtet"), a small outdoor kiosk found in many towns in West Greenland. Hunters and fishers in West Greenland also sell goods privately to other households, directly to institutions such as schools and senior citizens' homes, and to state-owned processing plants. These marketing opportunities complement non-monetized patterns of sharing and exchange within and between families and communities that continue to be important in Greenlandic society (Petersen, 1988).

\section{DISTRIBUTION AND EXCHANGE IN WEST GREENLAND BEFORE EUROPEAN COLONIZATION IN 1721}

Before Danish-Norwegian colonization in 1721, Greenlandic systems of sharing and exchange were based largely on generalized reciprocity (Petersen, 1988). In this pre-contact era, Greenlanders numbered less than 10000 people, and they wintered in numerous dispersed settlements along the coast. They relied primarily on sealing, whaling, bird hunting, and localized fishing for their livelihoods. The extended family groups were to all practical purposes selfreliant. When large marine mammals were caught, the catch was shared among all community members according to well-known rules and practices. For those unable to hunt for themselves, such as widows and orphans, this distribution of meat, blubber and mattak (whale skin) was particularly important, as it provided a sense of security and social solidarity.

Petersen (1988) describes two instances during this era in which Greenlanders regularly practiced a different form of exchange: balanced reciprocity. In the first instance, a household incapable of meeting its own needs might compensate another for goods or services. For example, a household 
needing a sealskin might barter for one by exchanging fish. In the second instance, a person might "pay" an angakkoq (shaman) for performing a ritual or for telling special stories.

Another example of balanced reciprocity was Greenlanders' participation in interregional trade and barter. Cranz (1767) and Gulløv (1985) describe a robust exchange economy in West Greenland in the precontact and early contact period. Household members traveled in summer by kayak and umiaq to well-known central summer camps (aasiviit, singular: aasivik), where they would exchange soapstone, whale baleen, and driftwood for other items not available locally. At these camps, they could also visit with distant family members, find a spouse, or consult with an angakkoq from far away.

\section{EUROPEAN COLONIZATION AND INCIPIENT ECONOMIC SPECIALIZATION}

Before European contact, the division of labor among Greenland's resident population was largely kin-ordered and sexually defined. Apart from the interregional exchange at summer camps, Inuit family units were largely self-sufficient. A family unit no longer able to provide for itself (e.g., through loss of a male provider) would normally join kindred family units.

Under those conditions, there was no need for formalized markets for country foods. With colonization, however, all this began to change. In the aftermath of Danish colonization in 1721, local markets for country foods arose in response to various colonial policies and practices. Foremost among these was the rapid creation of a specialized clerical and commercial workforce designed to serve the presumed religious needs of the local population, and the needs of DanishNorwegian commercial and financial interests. For much of the first 50 years of colonization, the latter consisted of privately owned trading companies created by royal charter. As Europeans inexperienced in arctic conditions, the members of this immigrant population were unable to live on their own in the same self-sufficient way as the Inuit. Their special skills were of no use when it came to foraging in an arctic setting. Like the corresponding communities of Orkneymen and other British traders who manned the forts and factories of the Hudson's Bay Company, they had to be supplied from an external source (Ray and Freeman, 1978; Judd, 1984; Thistle, 1986). With the presence of these dependent economic units in Greenland, conditions were ripe for the formation of local markets for country foods.

In 1774-76, the Royal Greenland Trade Department (Den Kongelige Grønlandske Handel or KGH) took over management of trade in Denmark's colonial empire in West Greenland. At about the same time, the geographical expansion of the Danish-Norwegian trading empire came to a stop ( $\mathrm{Gad}$, 1973). Its trading area would not change significantly until the colonization of the Ammassalik district in the late 19th century. In 1782, the KGH divided West Greenland into two inspectorates, each headed by its own colonial administrators (Inspekt $\phi r$ ). These inspectorates consisted of 13 trading stations (Danish, kolonier) stretching from $60^{\circ} \mathrm{N}$ latitude northward to about $72^{\circ} \mathrm{N}$. The colonies (with Danish names in brackets) in the Southern Inspectorate were Qaqortoq [Julianehåb], Paamiut [Frederikshåb], Qeqertarsuatsiaat [Fiskenæsset], Nuuk [Godthåb], Maniitsoq [Sukkertoppen] and Sisimiut [Holsteinsborg]. Those in the Northern Inspectorate were Aasiaat [Egedesminde], Qeqertarsuaq [Godhavn], Qasigiannguit [Christianshåb], Ilulissat [Jakobshavn], Appat [Ritenbenk], Uummannaq, and Upernavik (Fig. 1).

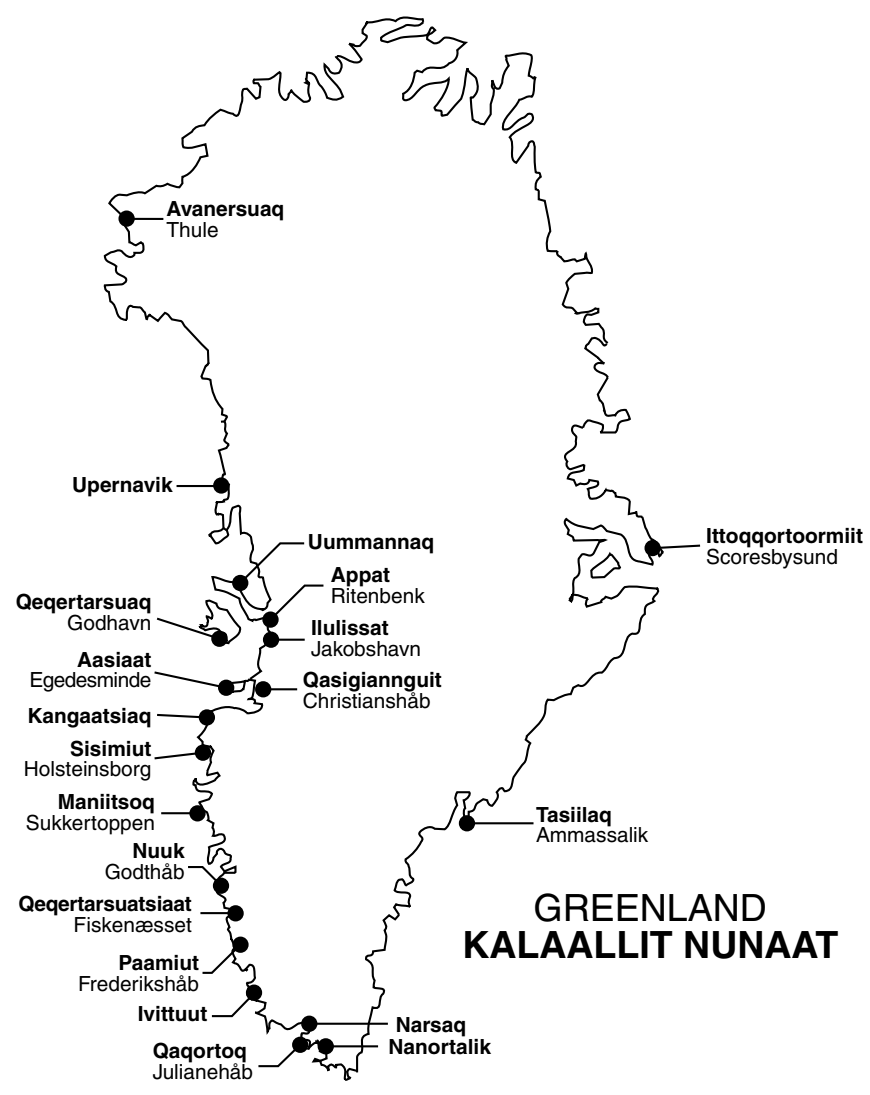

FIG. 1. Map of Greenland (Kalaallit Nunaat).

While the total number of trading stations might seem small in such a vast land, the number was in fact rather large considering the small indigenous population. Around 1780, only about 6000 to 7000 people lived in West Greenland and in 1855 their number was just about 9500 . This amounted to between one-and-a-half and two stations for every 1000 inhabitants in the land. By the late 1820s, plans were laid to build a new array of outposts, each linked to the larger stations. Development of these over time meant that by the 1860s, there were over 60 stations and outposts in West Greenland, employing a rather large number of people (Rink, 1877). In the mid-19th century this fact drew criticism from a number of Danish politicians, one of whom commented as follows:

The costs of the administration of the Greenland Trade are in no proportion to the size of the turnovers [of the trade]. Frankly speaking, the size of its turnovers are only equivalent to those of a great retail-trade. Consequently 
they are of a size that a commercial firm with just 2 or 3 shop-stewards would be able to handle in a punctual and accountable way. (Folketinget, 1862-63:181, O. Marquardt translation)

Between 1850 and 1880, 230-270 persons annuallythat is, approximately $2.5 \%$ of the total population of West Greenland at that time-earned their livelihood as employees of the KGH (Marquardt, 1993). If one calculates the number of household members - provider, family members, and possibly domestic servants - who could be considered dependent upon the KGH between the 1860s and 1880s, we find that $10-13 \%$ of the resident Greenlandic population was in such a position (Marquardt, 1993). Furthermore, in 1860, the KGH employed $14-15 \%$ of all male providers. In 1880, comparable employment totaled $11-12 \%$ (Folketællingen i Grønland, 1860; Marquardt, 1993). In short, in the second half of the 19th century the KGH had one employee for every 7-9 independent seal hunters.

In the latter half of the 19th century, those employees were for all practical purposes almost completely occupied with and economically dependent upon income from their employment (Marquardt, 1993). However, KGH employees were not the only ones in Greenland who performed specialized non-foraging activities. Although their activities were of a different kind, the employees of two missionary churches, the Danish (Lutheran) Mission and the Moravian Brethren (Herrnhutian Mission), did exactly the same. These included European missionaries and, after 1845, faculty at colleges for catechists and teachers in Greenland. For Greenlandic catechists and readers, who constituted the middle and lower ranks of the church hierarchy, things looked rather different. Almost every catechist of the Herrnhutian Mission was much more occupied with being a hunter and fisher than he was with being a religious servant. For a long period, the same applied for most of the catechists and readers (some of whom were female) of the Danish Mission. According to the census of 1855 , there were 95 catechists and readers with the Danish Mission in the Southern Inspectorate (Folketællingen i Grønland, 1855), but in the eyes of the acting inspector of that year, H.J. Rink, only 13 of these earned most of their livelihood through wages (Rink, 1857). In short, in the late 1800 s $40-50$ employees were economically dependent upon income from their employment as missionaries or catechists.

\section{GREENLANDIZATION OF COLONIAL ENTERPRISES IN THE 19TH CENTURY}

Throughout the 19th century, the number of indigenous Greenlanders among the employees in the middle and lower ranks was steadily rising. This included a growing number of those with mixed European/Greenlandic parentage. Not all observers were pleased with this situation. Samuel Kleinschmidt, a renowned linguist who developed the orthography for the West Greenlandic language, lamented in 1862 that: to bring about in Greenland the modern bourgeois civilization or some of its special traits will...cause material decay for the population...There are already more than enough who do not have hunting as their main trade. These people...have to be supplied by others with products from the land...Consequently, there is a rather narrow limit beyond which the division of labor-insofar as such a thing can be established at all-must not spread. The simple fact is that a Greenlander must be able to provide for himself all the necessities of his household and his hunting equipment. Otherwise there simply is no future. (Kleinschmidt, 1862:57, O. Marquardt translation)

If no consideration is given to the issue of full-time versus part-time employment, then the ratio of indigenous Greenlanders to Europeans employed was clearly highest with the Danish Mission and lowest with the KGH. Thus in $1860,92 \%$ of the employees of the Danish Mission and 80\% of the employees of the Herrnhutian Church were indigenous Greenlanders. Within the KGH, only $57 \%$ were Greenlanders (Folketællingen i Grønland, 1860). However, these percentages can be misleading if they are taken at face value, because of differences between full-time and part-time employment. If the ratio of indigenous Greenlanders to Europeans employed is computed only for those employees of the Danish Mission who were full-time or nearly full-time, then Greenlanders constituted $60-80 \%$ of all employees in the period $1850-80$.

In the three decades following 1850 , approximately 300 male providers in West Greenland were permanently attached and occupied full-time as employees. Most of them $(70-80 \%)$ were employed by the KGH. Broadly speaking, this means that $15-20 \%$ of the overall total of male providers secured their livelihood through specialized jobs that were completely foreign to the traditional Inuit foraging society. Thus, as a consequence of colonialism, economic specialization and an expanded division of labor obtained a firm footing in West Greenland. And more than half of those holding these positions were indigenous Greenlanders.

\section{EMERGENCE OF LOCAL MARKETS FOR COUNTRY FOODS IN THE 19TH CENTURY}

The emergence of local markets for country foods in Greenland was influenced by two major policies of the Danish colonial administration. The first allowed both commercial and church employees to purchase certain locally procured foods and other goods. The second policy restricted the type and amount of goods that colonial authorities licensed to be traded freely to the Greenlanders. This policy fostered interest in secondary trade outside of normal channels between colonial employees and Greenlanders.

For more than a century, colonial employees in Greenland were paid both in cash and in kind. In Danish, the latter payment was called a kostdeputat. This in-kind payment consisted of a standard array of provisions. Typical for the 
time, the deputat of the senior officers was more elaborateand consequently had greater value - than that of the ordinary employees. The kostdeputat was provided not only to the Danes but also to indigenous Greenlanders as they began to obtain permanent positions with the Danish Mission and the $\mathrm{KGH}$. Various philosophical and economic considerations caused Greenlandic employees to receive cash and in-kind payments that were somewhat lower than those of their European counterparts (Sveistrup and Dalgaard, 1945). In 1870, when the kostdeputat of the ordinary KGH employee was substituted for a cash payment, the value of the kostdeputat of a Greenlander was 25\% lower than that of his Danish colleague (Baumann, 1782-1903).

However, employees of the $\mathrm{KGH}$ and the church were not expected to live exclusively on imported European provisions. Colonial authorities allowed their resident agents in Greenland to buy from Greenlanders the so-called "refreshments" (Danish, forfriskninger): that is, locally procured fresh food products such as meats and berries. These were desirable as a means of combating scurvy. This approved trade in refreshments provided incentive for development of local markets for country foods.

The authorities were deeply concerned, however, that this local trade might undermine the general profitability of the KGH by hindering the trade of goods for European markets at the official trade shops. Prior to 1774-76 and the establishment of the $\mathrm{KGH}$, colonial traders had sought to maintain a trade monopoly. It was no surprise, then, when in 1782 it was officially ruled that the purchase of certain local products, the so-called "monopoly goods" (Danish, monopolvarer), was a prerogative of the KGH (Gad, 1973).

No one, whoever he may be and irrespective of his being either employed by the KGH or the Mission, or single or married, is allowed to buy from the Greenlanders or to procure for himself through illicit trade with others the articles that belong to the KGH...These articles are blubber, seal oil, baleen, furs or skins of bears, caribou, seals and foxes, horns (tusks) of the narwhal, teeth of the walrus, eider-down and some other articles.... (Instrux, 1782: chapter 3, O. Marquardt translation)

If for some reason an employee needed an article that was designated as a monopoly good, then the rules prescribed the correct procedure to follow:

If anyone... should be in need of these very articles [i.e., monopoly goods], then he may buy at the KGH shop what he needs, and he shall have it for a fair price.... In case the wanted articles are not to be had at the trade shop, whereas they are to be found in the custody of some Greenlander, who can do without them, and in case also that one of the employees really needs the articles in question, then the Greenlander shall bring the articles to the Chief Factor, who will pay him with goods that may legally be sold to Greenlanders. The goods given to the Greenlander shall be put to the debit of the employee's account, and the
Chief Factor must most carefully ensure that no embezzlement will take place and that the price given to the Greenlander...will not be so high that the effect will be the pampering of the natives. (Instrux, 1782: chapter 3, O. Marquardt translation).

In 1785, just three years after the issuing of the above Instrux, an official decree allowed missionaries to buy monopoly goods for their personal use directly from the Greenlanders (Baumann, 1782-1903). Apart from this limited allowance, however, the rules of 1782 were the official law of the land for more than a century. Significantly, the restrictions concerning monopoly goods did not apply to the meat of sea mammals and caribou or to birds and fish. Employees could buy these freely as refreshments on a purely private basis.

In the eyes of the employees, the local market had two main attractions. First, employees could enjoy fresh meats, birds and fish instead of living exclusively on a diet of salted, smoked, or dried (European) meat and bacon combined with dried peas, ship biscuits, etc. Second, if an employee could trade part of his kostdeputat with a Greenlandic hunter for country foods, he could reap an economic profit. He could convert unused parts of the kostdeputat into credit on his account with the $\mathrm{KGH}$, which could later be refunded in cash. That employees were aware of these economic opportunities can be seen in a letter sent in the 1840s from a Danish missionary in Sisimiut to his mother in Denmark.

I bought [from some Greenlanders] one hundred pounds of caribou meat for one Rigsbankdaler and four Skilling; that is, one Skilling per pound. I also bought two wonderfully speckled sealskins, which I can have made into a pair of trousers for myself, and some caribou skins that can be made into a coat. You see, Dear Mother, by virtue of my having come into possession of all the cheap meat and fish, I can avoid using my so-called Senior Officer's deputat. Later on, I then get a refund in cash. (Janssen, 1844-49:49, O. Marquardt translation)

The local markets also proved beneficial to Greenlandic hunters. First, hunters could take advantage of a market outlet for products (meats, birds, fish, etc.) that the $\mathrm{KGH}$ as an institution was unwilling to buy. Second, as colonial authorities for a long time put restrictions on the type and extent of products available to Greenlanders, many hunters wanted to trade privately with employees for items not officially approved as "Greenlanders' goods" (Danish, Grønlandervarer). This they could do by offering country foods, locally produced skin clothing, etc. as the medium of exchange. This trade, while technically illegal, was common practice. Eventually, officials tacitly acknowledged it and expanded the range of "Greenlanders' goods" that could be traded legally.

Thus the predecessor of today's kalaalimineerniarfik began as a local market where hunters could obtain goods not normally available to them and colonial employees obtained goods to fend off scurvy and to extend their limited cash 
salaries. Unfortunately, details about the extent of this early trade in country foods are difficult to obtain, because - unlike official KGH statistics on purchases from hunters-little or no direct documentation of it exists.

The function of these early markets changed with new colonial policies. Since about the 1830 s, a more liberal policy in the KGH had expanded the variety of goods categorized as "Greenlanders' goods." In the trade shops of circa 1860, differentiation between items available for colonial employees and those available for Greenlanders had largely disappeared (Bendixen, 1917). Thus, instructions to the two inspectors issued in 1876 noted that in general "it must be left to the discretion of the native-borns to...set the proper limits to their consumption of European goods" (Baumann, 17821903:203). However, the final abolition of employees' privileged rights to consume certain items, such as alcohol, did not occur until after World War II.

In 1846, colonial authorities began the process of eliminating the age-old kostdeputat by issuing a decree that the catechists of the Danish Missions should have their pay in cash only (Baumann, 1782-1903). It took some years to implement the new policy fully, but evidence from the districts of Qaqortoq, Qeqertarsuatsiaat and Nuuk shows that after 1855, every catechist was paid fully in cash (Royal Greenland Trade, 1849-1873). By 1870 a similar change in wage policy had been carried through for the ordinary KGH employees. From then on, they received additional pay calculated to replace the former kostdeputat. In 1888, this reform came to apply to the senior officers of the $\mathrm{KGH}$ as well (Baumann, 1782-1903; Royal Greenland Trade, 1888). The change in wage policy, like those policies doing away with limits on goods sold to Greenlanders, altered the original basis for the kalaalimineerniarfik. Broadly speaking, on the local markets the policy changes led to a situation in which payment in cash was much more frequent. Barter still occupied a central role, but the monetization of the market transactions received an important stimulus.

The fact that indigenous Greenlanders held a majority of permanent positions in the KGH and the Danish Mission around the mid-19th century means that the local markets of that time were not just a matter of external commoditization, with Danish employees alone buying country foods. It was also a matter of internal commoditization involving Greenlanders as buyers of country foods. Despite these changes, Greenlanders also continued kin-based sharing practices in many settlements (R. Petersen, 1991). These practices countered the notion of Greenlanders moving inevitably through a rigid mechanical transition toward a society which "reduce[s] the relations between human beings to a question of nothing else but the naked interest and the unemotional payment in cash on delivery" (Marx and Engels, 1848:820). But the changes were significant nonetheless. As Greenlandic politician and editor Kristoffer Lynge expressed it in 1926:

Until a generation ago people in Greenland lived almost exclusively from the hunting of seal, walrus and caribou and the catching of birds...This way of life very slowly disappeared. First it disappeared at the colonies [factory townships] where a lot of Greenlanders lived as permanently employed and salaried workers and where day-labourers were hired when times were busy. Thus it became a natural thing to the seal hunter to sell his products to the employed instead of following the old tradition of giving them away for nothing... That many people nowadays take on the habit of working for money causes the number of hunters practicing the old Greenlandic trade to become ever smaller... As a consequence, the prices of all Greenlandic products have risen and are still rising... Of course it is only natural that the hunter wants to receive pay for his products, but the wages of the nativeborn employees are too small to meet the natural demands of our times. (Lynge, 1926:65-67, O. Marquardt translation)

To summarize, the kalaaliminerniarfik initially arose in the 18th century to meet the needs of the employees of the church and the KGH and its predecessors. Originally these employees came from Denmark and Norway, but by 1850 , indigenous Greenlanders made up the majority. Significantly, the local markets served as a sort of "leveler" of differences between Greenlandic hunters and their countrymen working for the colonial authorities. They served as a redistribution channel whereby hunters received European goods (or cash to buy them), while Greenlandic and Danish salaried employees received valued country foods and locally produced items of clothing or other goods. Without the local markets, a more stark separation might have developed between Greenlanders employed by colonial authorities and those selling products of the hunt. If paid employees had not had access to country foods, they might well have been much more dependent upon foods and other supplies from the $\mathrm{KGH}$. Cultural traditions of eating marine mammal products and other local foods may well have been disrupted, perhaps accelerating acculturative forces. At the same time, without local markets for country foods, hunters would have been restricted in terms of European goods available to them and would have been without an important source of cash.

\section{GREENLANDIC MARKETS FOR COUNTRY FOODS IN THE 20TH CENTURY}

Local markets for country foods continue to exist in Greenland in the 20th century. Today one can find a kalaalimineerniarfik in most major towns in West Greenland, including Nuuk, Sisimiut, Paamiut, Qaqortoq, and Ilulissat (Falk and Durinck, 1992). They also exist in smaller towns, but these may be used only sporadically. In most cases, the market is housed in a small open-air kiosk that has concrete floors (for easy cleaning) and tables for displaying foods. These structures are usually located near the harbor, convenient to returning hunters and fishers. The first structure constructed specifically to house a kalaalimineerniarfik was apparently built in Nuuk in 1958 (Egede, 1989; 
R. Petersen, pers. comm. 1992). Today, most are built and maintained by the local municipal government.

However, the kalaalimineerniarfik today is part of a wider system of production, distribution, and exchange of country foods supported by Greenland's Home Rule Government. Greenlanders today number some 55000 people, over $80 \%$ of whom identify themselves as indigenous (Inuit) people. Nearly $90 \%$ of the total population resides in West Greenland, living in towns and settlements ranging in size from 40 or 50 up to nearly 13000 (in Nuuk, the capital city). Modern Greenland under Home Rule is increasingly dependent on the world economy for imports and exports (Lyck, 1990; Paldam, 1994). Today, over $90 \%$ of Greenland's export earnings come from a single commodity, cold-water shrimp, which is sold in Europe, North America, and Japan. Greenland also has an increasing urban population, over three-quarters of which is involved in wage employment.

The Home Rule government's system for marketing country foods is designed to help reduce dependency on imported goods. Government policies underwrite procurement of country foods, particularly in smaller settlements in the municipalities of Upernavik, Avanersuaq (Thule), Ammassalik, and Ittoqqortoormiit (the so-called "hunting districts"). Nearly all types of country foods are exchanged through this system, but the most prominent are seal meat, beluga, and narwhal mattak, meat and mattak from minke and fin whales, caribou, fish, and sea birds (particularly murres and eider ducks).

Hunters and fishers today have at least four avenues for marketing country foods. The first is to sell them privately to households within a community. The second is to sell foods privately to local institutions such as schools, senior citizens' homes, or hospitals. The third avenue is to sell country foods at the kalaalimineerniarfik. The final avenue is to sell foods to the government-controlled Royal Greenland processing plant and its subsidiary GFI (Godthåbs Fiskeindustri A/S) in Nuuk. Royal Greenland then distributes these products to shops throughout Greenland.

In the first two of these marketing options, hunters make their own arrangements with local households or institutions to sell country foods at an agreed-upon price (which may be fixed locally; see below). In some cases compensation might be simply in cash. Research from 1993 reveals that hunting families average about $2500 \mathrm{DKr}$ (about US\$450) annually from such sales (Greenland Statistical Office, 1995). Institutions often have regular arrangements with well-known hunters or fishers to provide meat and fish, or they may simply post a sign locally offering to buy country foods from whoever has them available. For example, in 1993, the senior citizens' home in Qeqertarsuaq purchased from hunters 530 $\mathrm{kg}$. of seal meat, $203 \mathrm{~kg}$. of whale meat, $33 \mathrm{~kg}$. of whale mattak, 20 murres, and 15 eider ducks (Greenland Home Rule Government, 1994). The total estimated value of these products was $49165 \mathrm{DKr}$, or about US $\$ 8900$. In private sales, compensation other than cash may also be involved. In another example from Qeqertarsuaq, a household exchanged seal meat, fish, and a small amount of cash for a typewriter needed by a young member of the family.
The third avenue for selling country foods is at the kalaalimineerniarfik. Significantly, hunters selling foods there do so at a fixed price agreed upon by the local hunters' and fishers' association (Kalaallit Nunaat Aalisartut Piniartullu Kattufiat, or KNAPK) and by municipal authorities (usually a local consumers' committee). Prices are usually set for one or two years, but can be renegotiated if necessary. The negotiated agreement takes into account the costs of hunting and fishing, including changing costs of gasoline and equipment like outboard motors. It may also take into account other factors, such as actions of other countries to prohibit importation of sealskins. Once an agreement is reached, there is no bargaining or competitive marketing at the kalaalimineerniarfik. Prices are posted at the kiosk itself and are distributed widely in the community. Research from 1993 indicates that active hunting households throughout Greenland earn an average of $8000 \mathrm{DKr}$ (about US\$1450) annually from such sales (Greenland Statistical Office, 1995). Table 1 shows fixed prices (converted to US\$/kg) used for country foods in Qeqertarsuaq Municipality, West Greenland for 1993 and 1994.

Table 1 provides some idea of the range of products potentially available at a local kalaalimineerniarfik. However, in most cases, the array of goods available will be limited by factors such as seasonal availability and hunting regulations. Caulfield's (1991) observations of sales at Qeqertarsuaq's kalaalimineerniarfik between September 1989 and July 1990 revealed that the types of foods most frequently sold were fish ( $26 \%$ of all foods sold, by type), seal products $(22 \%)$, beluga or narwhal products $(14 \%)$, and caribou (14\%).

In many communities, hunters and fishers start their day at about 4:00 a.m., departing in a skiff or (in winter) by dog team to known hunting or fishing sites. Typically, they return to town about 9:00 or 10:00 a.m. to sell their products. In most places, hunters remain to sell their own catch. However, in Nuuk a relatively new practice has started. A middleman or tuniniussisartoq may sell products on behalf of local hunters, taking a small percentage (usually 10 to $20 \%$ ) for his services. This enables hunters to go back out for more hunting or fishing rather than having to stay and sell their foods to others.

In Greenland, the kalaalimineerniarfik not only serves an economic function but also provides an important social gathering place for hunters and fishers, who are almost exclusively men. In this sense, the market provides a place for sharing information and news not unlike that described by H.C. Petersen $(1991: 55,57)$ from an earlier era:

[At the turn of the 20th century] the men had a specific place where they met and discussed the issues of the day. The place was next to the kayak racks. Here men discussed politics and social issues...but the most frequently discussed subject during this gathering was the account of the day's hunt. With great insight and many hand gestures, the hunter would relate events leading up to the kill. He wouldn't forget even the slightest detail. It was all so vivid that one felt as if he was right there during the hunt. (R. Caulfield translation) 
TABLE 1. Prices (in US\$) for selected country foods sold in Qeqertarsuaq Municipality, 1993-94.'

\begin{tabular}{lc}
\hline \hline Product & Price \\
& US\$/kg unless specified otherwise; \\
& 1 US $\$=6.2 \mathrm{DKr}$ \\
\hline ringed seal meat (caught with a rifle) & 7.26 \\
ringed seal meat (caught with a net) & 5.65 \\
harp or hooded seal meat & 4.03 \\
seal liver & 6.45 \\
beluga or narwhal flipper or tail & 9.68 \\
beluga mattak & 19.35 \\
minke whale meat & 5.65 \\
minke whale ventral grooves & 8.07 \\
walrus meat & 1.61 \\
polar cod (fresh) & 2.42 \\
cod (fresh/whole) & 3.23 \\
wolf-fish (gutted) & 3.23 \\
halibut & 6.45 \\
arctic char (fresh) & 6.45 \\
cod, wolf-fish, polar cod (dried) & 16.13 \\
cod (dried whole) & 8.07 \\
capelin (dried) & 11.29 \\
Greenland shark (fresh and for dogfood) & .81 \\
lumpfish & 4.84 each \\
common eider & 6.45 each \\
thick-billed murre & 4.84 each \\
black-legged kittiwake & 3.23 each \\
rock ptarmigan & 5.66 each \\
\hline \hline
\end{tabular}

${ }^{1}$ Source: Kalaallit Nunaat Piniartut Aalisartullu Katuffiat (KNAPK), 1993.

The fourth and most extensive system for processing and distributing country foods is through the Home Rule-controlled company, Royal Greenland A/S, and its wholly owned subsidiary GFI (Godthåb Fiskeindustri) in Nuuk. Royal Greenland is the flagship of Home Rule enterprises and has primary responsibility for producing, processing, and marketing the products of Greenlandic fisheries. Royal Greenland has 16 processing plants and over 40 smaller processing facilities throughout Greenland. In recent years, Royal Greenland has undergone major restructuring as the Home Rule leadership seeks to make it more competitive on world markets. GFI handles virtually all of Royal Greenland's production of country foods for the home market (C. Petersen, pers. comm. 1992). These foods include all marine mammal products, many species of fish, Greenlandic lamb, and seabirds. In 1991, GFI sold about US\$5.5 million worth of country foods in local markets.

Since about 1988, Greenland's political leadership has sought to strengthen the home market for country foods to reduce imports and support hunters in outlying settlements. Before 1988, hunters could sell country foods locally to the nearest processing facility, which would then prepare the products for distribution. Since that year, however, Home Rule authorities have tried to reduce processing costs and make this system more efficient by dedicating specific plants to processing certain types of foods. Today, four plants in West Greenland process all of Greenland's country foods for distribution to local stores. For example, the plant in Ilulissat processes only Greenlandic halibut, while the plant in Narsaq processes Greenlandic lamb. A plant in Qaqortoq processes mostly marine mammal products. The main GFI plant in Nuuk processes all other products (e.g., seabirds, other fish).

Once country foods are processed by GFI, they are shipped to Nuuk for distribution throughout Greenland. Generally, about $60-65 \%$ percent of all products are sold to Home Ruleowned retail stores. The remainder are sold to other private retail outlets for resale. GFI typically earns about $15 \%$ profit on sales to KNI (Kalaallit Niuerfiat, or Greenland Trade) and to other outlets. Prices paid to hunters for products delivered are determined once a year by agreement between Royal Greenland/GFI and KNAPK, the hunters' and fishers' association. Negotiations between KNAPK and Royal Greenland/GFI are not always cordial. For example, in 1991 KNAPK members staged a demonstration on the steps of Royal Greenland's offices in Nuuk demanding better prices.

In 1992, the Home Rule government implemented a new policy regarding sales of country foods, which reduced prices charged to consumers up to 30\% (Anonymous, 1991; Greenland Home Rule Government, 1994). The price for certain types of whale meat, for example, was reduced to about $\$ 6.00$ per kilo, making it more competitive with imported hamburger, which costs about $\$ 10.00$ per kilo. These reductions were accomplished in part by improving efficiency in processing rather than by lowering prices paid to hunters. Price reductions also made GFI products more competitive with those at the local kalaalimineerniarfik. As a result, hunters in a few locations decided to lower prices in the outdoor markets. In Nuuk, however, hunters expressed satisfaction that the fresh products sold at the kalaalimineerniarfik will remain competitive over those processed and frozen by GFI.

\section{HOME RULE AND RENEWABLE RESOURCE MANAGEMENT}

The Greenland Home Rule Government regulates all hunting and fishing in Greenland under the Nature Conservation Act, first adopted in 1980 and revised in 1988 (Helms, 1991). Under the Act, all hunters and fishers must have a license as either full-time (Greenlandic, piniartut inussutisarsiutigivillugu) or sport (piniartut inussutisarsiutigivinagu) hunters and fishers. The type of license one receives is based on several criteria. All commercial fishermen receive the fulltime license. Furthermore, those who are unemployed for more than 125 days of the year (i.e., who are seasonally employed) can also qualify for a full-time license. Licenses are renewed annually so long as the hunter completes a report specifying how many fish or animals were caught. In 1994, over 7000 licenses were issued, 3099 to full-time hunters and 4100 to sport-hunters (Greenland Home Rule Government, 1995).

Regulations adopted under the Act are enacted following input from local hunters and fishers, biologists, KNAPK, and officials involved with management of species of interest outside of Greenland, including beluga and narwhal (Helms, 1991). Furthermore, local municipalities may also adopt regulations governing the methods and means used in taking fish and wildlife within their boundaries. 
They also regulate use of the kalaalimineerniarfik. Within the Home Rule administration, a natural resources office monitors resource harvests and manages a recently established corps of fish and wildlife officers who are responsible for monitoring resource use.

The 1988 act allows the sale of most species of fish and wildlife in Greenland, subject to appropriate regulations. In some cases, these regulations are quite liberal. In others, such as for whales, caribou, and seabirds, they are more stringent. For example, concern about murre populations led the Greenlandic Parliament (Landsting) to enact special regulations closing the season for murres in some areas, prohibiting the sale of murres in others, and restricting murre hunting to those with full-time hunting licenses (Falk and Durinck, 1992). Similarly, a decline in caribou numbers led the Home Rule government to implement a two-year ban on caribou hunting in 1993 and 1994.

Some biologists question the effectiveness of Home Rule regulations (Falk and Durinck, 1992). They point to administrative decisions exempting hunters in some areas from regulations, and to extensions of hunting seasons beyond normal closures. However, the Home Rule government's recent decision to hire enforcement personnel suggests that it recognizes the importance of increasing public awareness of conservation regulations. It also has an active information and education program to incorporate hunters' knowledge into wildlife management and to inform local people about results of scientific research.

\section{COUNTRY FOODS AND SUSTAINABLE DEVELOPMENT IN GREENLAND'S FUTURE}

Greenland's system for producing, distributing, and exchanging country foods for local markets is a central element in its strategy for sustainable community development (Greenland Home Rule Government, 1995). By supporting this system, the Home Rule government reduces the need for imports, promotes indigenous hunting practices, offsets the need for government subsidies to smaller settlements, and encourages consumption of nutritious and culturally valued foods. As Table 2 shows, Greenland continues to import large quantities of processed meats. In 1994, Greenland imported meats and meat products valued at over 85 million $\mathrm{DKr}$

TABLE 2. Greenland's imports of meat products, 1991 and 1992, in metric tons. ${ }^{1}$

\begin{tabular}{lrr}
\hline \hline Type & 1991 & 1992 \\
\hline Sausage (pølser) & 575.1 & 558.8 \\
Beef & 682.0 & 647.6 \\
Pork & 1548.4 & 1507.0 \\
Other & 965.6 & 755.5 \\
Total meat imports & & \\
& 3771.1 & 3468.9 \\
\hline \hline
\end{tabular}

${ }^{1}$ Source: Greenland Statistical Office, 1994.
(US\$15.4 million). One goal of the Home Rule government is to reduce this level of imports by supporting procurement of country foods. Indeed, since the implementation of new government policies in 1992, the cost of these imports has declined by about $12 \%$.

But can this policy of promoting country foods be sustained? As noted above, Langdon (1991) found that there was no significant, unambiguous effect of cash and commoditization on local economies. Rather, his research in Alaskan Eskimo communities suggests that subsistence and cash can complement one another when 1) human population densities are low relative to natural resources, 2) resources are in adequate supply and not degraded, 3) external demands for resources are limited, 4) demands of the commercial sector are within the capabilities of local people, 5) indigenous land and sea tenure systems are sustained, 6) local production is not appropriated by taxation, 7) production units remain kin-based, and 8) cash is not fetishized.

If we examine Langdon's factors in Greenland, we find that the human population has grown significantly, especially since the turn of the century. In 1900, the total population of Greenland numbered about 11000 people. Today, it is over 55000 people, and an increasing proportion of those people live in larger settlements having more than a thousand people. Yet, by most standards, population densities remain very low in Greenland as a whole. Furthermore, the rate of population growth is likely to slow in the years ahead (Paldam, 1994). However, resource conflicts could develop locally near towns like Nuuk, Sisimiut, and Qaqortoq, where population densities are increasing.

A second question is whether resources are in adequate supply and are not degraded. While details about the status of individual species found in Greenland are beyond the scope of this paper, Greenlanders have access to a wide variety of living marine resources and a smaller number of terrestrial resources. The seal species most commonly consumed in Greenland (e.g., the ringed seal and the Greenland harp seal) number in the millions (Greenland Home Rule Government, 1994). That said, questions about biological sustainability are clearly central in evaluating Home Rule policies on domestic use of country foods. In Greenland, biological monitoring is carried out by the Greenland Natural Resources Institute (Greenlandic, Pinngortitaleriffik) in conjunction with appropriate Danish and international bodies (e.g., the International Whaling Commission and the North Atlantic Marine Mammal Commission). This is no small task in a vast and dynamic ecological setting. In recent years, biologists have recommended special regulations for seabirds, arctic char, some whale species, walrus, and caribou. As noted above, the Home Rule government has also implemented a new enforcement program involving fish and wildlife officers.

Langdon's third factor is whether or not external demands for resources are limited. In Greenland, country foods (with the exception of shrimp and fish species) are not exported. This reduces pressure on resource populations by limiting markets to the small Greenlandic population. Greenland's indigenous people are also well aware of the variability and 
seasonality of most country foods: they recognize that a regular, year-round supply of most country foods is not possible.

A fourth factor is whether the demands of the commercial sector are within the capabilities of local people. This is an area where Home Rule government policy is crucial. Building on long-standing indigenous harvest practices, the Home Rule government subsidizes the equipment and infrastructure necessary to make a Greenland-wide system of distribution possible. This policy, made at the highest levels of government, fosters expansion of existing systems because country food production and distribution are thought to provide widespread benefits to Greenlandic society.

The fifth factor-whether indigenous land and sea tenure systems are sustained-is also closely related to Home Rule laws and policies. Significantly, there is no private ownership of land in Greenland. All land is owned collectively by Greenlanders through the state. Use of specific places for houses or camps associated with hunting and fishing is based largely on usufructuary rights. Similarly, the state plays a predominant role in allocating marine resources through Home Rule and municipal laws and regulations. Thus, Home Rule provides Greenlanders with effective indigenous control over land and sea tenure systems.

Langdon's sixth factor focuses on whether or not local production is appropriated by taxation. Again, because Greenland has Home Rule, indigenous people themselves (through the elected Landsting) decide what taxation policies to impose on country food production. Indeed, this has been a source of some controversy in recent decades, since the government decided in 1975 to begin taxing production of country foods.

Langdon's final two factors focus on whether production of country foods remains largely kin-based and whether or not cash becomes fetishized in Greenlandic communities. Recent research (Møller and Dybbroe, 1981; Caulfield, 1991; Nuttall, 1992) indicates that, on the whole, production of country foods for local markets in Greenland remains largely kin-based, with the social organization of procuring country foods rooted in families and extended families. Production units are generally related through kinship and alliances, and capital is the property of the household. Capital investments come from current earnings obtained through production or wage labor, and the equipment used is relatively small-scale. Production of country foods is relatively unspecialized and doesn't involve sophisticated technology.

These findings suggest that in Greenland, hunters' primary goal in selling country foods is not to maximize profits but, using Freeman's (1993:iv) words, to "sustain their interdependent social, cultural and economic activities and institutions from generation to generation." In smaller Greenlandic settlements, cash obtained from procurement of country foods is largely used to buy fuel, new equipment, and ammunition (Greenland Home Rule Government, 1994). This situation contrasts sharply with Greenland's export fisheries for resources like shrimp and Greenlandic halibut. In these fisheries, economic specialization is pronounced and the technology used is highly sophisticated. Having made this distinction, however, we must add that it is also possible that further changes will take place in the country foods sector, such as that described above from Nuuk, where a "middleman" system has developed at the kalaalimineerniarfik.

The concept of sustainable development is increasingly important in the circumpolar North, as it is elsewhere in the world (Keith and Simon, 1987; Hansen, 1991). The Brundtland Commission's now well-known definition of sustainable development as that which "meets the needs of the present without compromising the ability of future generations to meet their own needs" may provide a hopeful vision for the future (World Commission on Environment and Development, 1987). Yet the notion of sustainability, while rich in symbolism, is also fraught with contradiction (Redclift, 1987; Griffiths and Young, 1989; Duerden, 1992). In the North, country foods are widely recognized as vital to indigenous strategies for sustainable development (Weeden, 1985, 1989, 1992; Griffiths and Young, 1989; Duerden, 1992). Yet demographic characteristics, resource use patterns, and local economies continue to change; and resource dynamics and biological uncertainty make managing for sustainability problematic (Weeden, 1985; Rees, 1988).

Some suggest that this uncertainty makes effective resource management impossible. Some animal rights groups, for example, argue that any commercial sale of fish and wildlife resources is inappropriate: that such sales violate basic principles of fish and wildlife management (see Keith and Saunders, 1989). However, Usher (in Keith and Saunders, 1989:84) argues for a different approach. Rather than opposing all commoditization of country foods on ideological grounds, he suggests, it may be better to evaluate each case on its merits:

If we look at [commercialization] carefully, on a case-bycase basis, we'll probably wind up doing reasonably well on it-about as well as we do in most other things in life. If we tend to get too dogmatic and suggest that 'in principle' there is something wrong with commercial exploitation, we will probably do more harm than good.

As this example from Greenland demonstrates, commercialization of country foods for local use has a history in the North. Greenland's system for producing and distributing country foods is an extension of that history, and illustrates that there is no "single set of consequences" (Peterson, 1991b:67) resulting from the sale of country foods. Rather, the Greenland example supports Peterson's (1991a:2) contention that

if economic activity is socially constituted...then it is possible that as well as being transformed by these external influences foragers may assimilate some, many or all of the intrusions and linkages with the dominant economy to their own internal social purposes and in so doing reproduce distinctive sets of economic and social relations. 


\section{ACKNOWLEDGEMENTS}

The authors would like to thank A. Jessen, R. Reeves, and one anonymous reviewer for comments on an earlier draft of this article. Data presented in this article were gathered in conjunction with research funded by the U.S. National Science Foundation, Arctic Social Sciences Program, and approved by the Commission for Scientific Research in Greenland. R. Caulfield would like to thank the following for their assistance and support: Rev. L.P. Berthelsen, the people of Qeqertarsuaq Municipality, C. Petersen, P. Lyster, Prof. R. Petersen, H.C. Petersen, Ilisimatusarfik (University of Greenland), and the University of Copenhagen's Arctic Station (Qeqertarsuaq). D. Jones at the University of Alaska Fairbanks skillfully prepared the map of Greenland. For their great and ever-ready help, O. Marquardt would like to thank archivist Else Marie Heilmann of Nunatta Katersugaasivia (National Museum and Archives of Greenland) and librarian Helle Raffnsøe at Ilisimatusarfik.

\section{REFERENCES}

ANONYMOUS. 1991. Atuisoq (Nuuk) 3:17. December 1991.

BAUMANN, H. 1782-1903. Samling af Instruxer og Bestemmelser vedrørende Grønland og den kongelige Grønlandske Handel. Unpubl. ms. Catalogue no. 65.08. Available at Nunatta Atuagaateqarfia [National Library], Box 939, 3900 Nuuk, Greenland.

BENDIXEN, O. 1917. Den grønlandske general-taxt og handel og omsætning ved kolonierne i gamle dage. København: Grønlandske Selskabs Aarsskrift. 1-9.

BURCH, E.S., Jr. 1988. Modes of exchange in north-west Alaska. In: Ingold, T., Riches, D., and Woodburn, J., eds. Hunters and gatherers. Explorations in Anthropology Series. Oxford: Berg Publishers Limited. 95-109.

CAULFIELD, R.A. 1991. Qeqertarsuarmi arfanniarneq: Greenlandic Inuit whaling in Qeqertarsuaq Kommune, West Greenland. Report presented to the International Whaling Commission Technical Committee. Report number TC/43/AS4. $139 \mathrm{p}$.

CRANZ, D. 1767. The history of Greenland: Containing a description of the country and its inhabitants. London: The Brethren's Society. 2 vols.

DAHL, J. 1989. The integrative and cultural role of hunting and subsistence in Greenland. Études/Inuit/Studies 13(1): 23-42.

DAMAS, D. 1984. Handbook of North American Indians. Vol. 5: Arctic. Washington, D.C.: The Smithsonian Institution.

DUERDEN, F. 1992. A critical look at sustainable development in the Canadian North. Arctic 45(3):219-225.

EGEDE, K. 1989. Suna tissinarami?! Aliikkusersuisartup aalisartup, piniartullu eqqaamasalersaarutai. Nuuk: Atuakkiorfik.

FALK, K., and DURINCK, J. 1992. Thick-billed murre hunting in West Greenland, 1988-1989. Arctic 45(2):167-178.

FOLKETÆLLINGEN I GRØNLAND [Greenland Census]. 1855 (published 1858). København: Statistisk Bureau. 1860 (published 1862). København: Statistisk Bureau. 1880 (published 1883). København: Statistisk Bureau.
FOLKETINGET [Danish Parliament] 1862-63. Rigsdagstidende. Copenhagen: Folketingets Forhandlinger.

FREEMAN, M.M.R. 1993. Introduction: Community-based whaling. Arctic 46(2):iii-iv.

GAD, F. 1973. The history of Greenland: Vol. 2, 1700-1782. London: C. Hurst \& Co.

GREENLAND HOME RULE GOVERNMENT. 1994. Redegørelse om fangererhvervet 1994. Nuuk: Direktoratet for Fangst, Fiskeri, og Landbrug. Box 269, 3900 Nuuk, Greenland. $135 \mathrm{p}$.

1995. Grønland 1995 Kalaallit Nunaat-Statistisk Årbog. Nuuk: Atuakkiorfik.

GREENLAND STATISTICAL OFFICE (Grønlands Statistiske Kontor) 1994. Indførsel af kød 1991-92 i tons. Unpubl. ms. Available from Grønlands Statistiske Kontor, Box 1025, 3900 Nuuk, Greenland.

1995. Fisker- og fangerfamiliers levevilkår: Rapport nr. 3 fra unders $\varnothing$ gelsen af befolkningens $\emptyset$ konomiske og materielle levevilkår [Fishing and hunting families' living conditions: Report No. 3 from research of the population's economic and material living conditions]. Available from Grønlands Statistiske Kontor, Box 1025, 3900 Nuuk, Greenland. 13 p.

GRIFFITHS, F., and YOUNG, O.R. 1989. Sustainable development and the Arctic: Impressions of the co-chairs. Hanover, New Hampshire: Working Group on Arctic International Relations, Report 1989-1. 30 p.

GULL ØV, H.C. 1985. Whales, whalers, and Eskimos: The impact of European whaling on the demography and economy of Eskimo society in West Greenland. In: Fitzhugh, W., ed. Cultures in contact: The impact of European contacts on Native American cultural institutions, A.D. 1000-1800. Washington, D.C.: Smithsonian Institution Press. 71-96.

HANSEN, B. 1991. Arctic environment: Indigenous perspectives. Copenhagen: International Work Group for Indigenous Affairs, IWGIA Document 69.

HEADLAND, T.N., and REID, L.A. 1989. Hunters-gatherers and their neighbors from prehistory to the present. Current Anthropology 30(1):43-66.

HELMS, H.J. 1991. Nature conservation in Greenland. In: Egede, I., ed. Conservation of nature in Greenland. Nuuk: Atuakkiorfik.

INSTRUX. 1782. Instrux, hvorefter kiøbmædene eller de som enten bestyre Handelen eller forestaae hvalfanger-anlæggene $i$ Grønland, i særdeleshed, saavelsom og alle de, der staar i Handelens tieneste $\mathrm{i}$ almindelighed, sig for fremtiden haver at rette og forholde. In: Bobé, L., ed. 1936. Diplomatarium Groenlandicum 1492-1814. Aktstykker og Breve til Oplysning om Grønlands Besejling, Kolonisation og Missionering. Copenhagen: C.A. Reitzels Forlag.

JANSSEN, C.E. 1844-49. En Grønlandspræsts Optegnelser 1844 1849. Clausen, J., and Rist, P.P., eds. 1913. Copenhagen: Glydendals Forlag.

JUDD, C.M. 1984. Sakie, Esquawenoe and the foundation of a dual-Native economy at Moose Factory. In: Krech, S., III, ed. The Subarctic fur trade: Native social and economic adaptations. Vancouver: UBC Press.

KALAALLIT NUNAAT AALISARTUT PINIARTULLU KATTUFFIAT (KNAPK) 1993. Tuniniaasarfimmi akit 1993- 
mit. Unpubl. ms. Available from KNAPK, P.O. Box 386, 3900 Nuuk, Greenland.

KEITH, R.F., and SAUNDERS, A. 1989. A question of rights: Northern wildlife management and the anti-harvest movement. Ottawa: Canadian Arctic Resources Committee.

KEITH, R.F., and SIMON, M. 1987. Sustainable development in the northern circumpolar world. In: Jacobs, P., and Munro, D.A., eds. Conservation with equity: Strategies for sustainable development. Proceedings of the Conference on Conservation and Development: Implementing the World Conservation Strategy. Ottawa, 31 May-5 June 1986. 209-225.

KLEINSCHMIDT, S. 1862. Brev til en dansk bekendt fra 13.8.1862. Grønlandske Selskabs Aarsskrift 1916:55-62.

LANGDON, S.J. 1986. Contemporary Alaskan Native economies. Lanham, Maryland: University Press of America.

- 1991. The integration of cash and subsistence in southwest Alaskan Yup'ik Eskimo communities. In: Peterson, N., and Matsuyama, T., eds. Cash, commoditisation and changing foragers. Osaka: National Museum of Ethnology. 269-291.

LEACOCK, E., and LEE, R. 1982. Politics and history in band societies. Cambridge: Cambridge University Press.

LYCK, L. 1990. International involvement, autonomy and sustainable development in the Arctic. Polar Record 26(159): 309-312.

LYNGE, K. 1926. Udviklingen i Grønland. Grønlandske Selskabs Aarsskrift 1925-26:61-69.

MARQUARDT, O. 1993. Socio-økonomiske tilstande i Vestgrønland på Rinks tid: antal fastansatte ved KGH og grønlandiseringen af $\mathrm{KGH}$-arbejdspladserne. Grønlandsk kultur- og samfundsforskning 93. Nuuk: Ilisimatusarfik.

MARX, K., and ENGELS, F. 1848. Manifest der kommunistischen Partei. In: Lieber, H.J., and Furth, P., eds. 1971. K. Marx, Frühe Schriften. Darmstadt: Wissenschaftlitche Buchgesellschaft.

MØLLER, P., and DYBBROE, S. 1978. Fangstens betydning i dagens Grønland. Jordens Folk 1978:7-15.

___ 1981. Fanger/fisker-Lønarbejder? En unders $\emptyset$ gelse af sammenhængene mellem fangst og lønarbejde i Godhavn, 1976 \& 1977. Aarhus: Institut for forhistorisk arkæologi, middelalder-arkæologi, etnografi og socialantropologi, Aarhus Universitet.

NUTTALL, M. 1992. Arctic homeland: Kinship, community and development in northwest Greenland. Toronto: University of Toronto Press.

PALDAM, M. 1994. Grønlands økonomiske udvikling: Hvad skal der til for at lukke gabet? Aarhus: Aarhus University Press.

PETERSEN, H.C. 1991. Grønlændernes historie før 1925. Nuuk: Atuakkiorfik.

PETERSEN, R. 1974-75. Some considerations concerning the Greenland long house. Folk 16-17:171-188.

- 1988. Traditional and contemporary distribution channels in the subsistence hunting in Greenland. In: Dahl, J., ed. Keynote speeches from the Sixth Inuit Studies Conference, Copenhagen, October 1988. Copenhagen: University of Copenhagen, Eskimology Institute. 81-89.

1991. Fangst og bosættelse. Studie fra to grønlandske fangersamfund I-II. Nuuk: Ilisimatusarfik.
PETERSON, N. 1991a. Introduction: Cash, commoditisation and changing foragers. In: Peterson, N., and Matsuyama, T., eds. Cash, commoditisation and changing foragers. Osaka: National Museum of Ethnology. 1-16.

1991b. Cash, commoditisation and authenticity: When do aboriginal people stop being hunter-gatherers? In: Peterson, N., and Matsuyama, T., eds. Cash, commoditisation and changing foragers. Osaka: National Museum of Ethnology. 67-90.

PETERSON, N., and MATSUYAMA, T. 1991. Cash, commoditisation and changing foragers. Osaka: National Museum of Ethnology.

RAY, A.J., and FREEMAN, D.B. 1978. Give us good measure: An economic analysis of relations between the Indians and Hudson's Bay Company before 1763. Toronto: University of Toronto Press.

REDCLIFT, M. 1987. Sustainable development: Exploring the contradictions. London: Routledge. 221 p.

REES, W.E. 1988. Sustainable development: Economic myths and ecological realities. Trumpeter 5(4):133-188.

REEVES, R.R. 1992. Recent developments in the commerce in narwhal ivory from the Canadian Arctic. Arctic and Alpine Research 24(2):179-187.

REEVES, R.R., and HEIDE-JØRGENSEN, M.P. 1995. Commercial aspects of the exploitation of narwhals (Monodon monoceros) in Greenland, with emphasis on tusk exports. Meddelelser om Grønland, Bioscience 39:119-133.

RINK, H.J. 1857. Grønland geographisk og statistisk beskrevet. Det søndre inspektorat. København: Klein.

1877. Danish Greenland: Its people and products. London: Henry S. King \& Co.

ROSING, O. 1984. Taseralik: Oqaluttualiaq 1845-50 missaani pisimasuullugu. Nuuk: Atuakkiorfik.

ROYAL GREENLAND TRADE (Den Kongelige Grønlandske Handel, KGH). 1849-73. Schematiske Indberetninger: Folkmængden i Grønland. Unpubl.ms. Nos. 882-885. Available in Rigsarkivet [National Archives]. Copenhagen.

- 1888. Meddelelser fra Direktoratet for den Kongelige Grønlandske Handel 1888, No. 2. Copenhagen.

SMITH, T.G., and WRIGHT, H. 1989. Economic status and role of hunters in a modern Inuit village. Polar Record 25:93-98.

SVEISTRUP, P., and DALGAARD, S. 1945. Det danske Styre af Grønland 1825-1850. Meddelelser om Grønland 145(1).

THISTLE, P.C. 1986. Indian-European trade relations in the Lower Saskatchewan River region to 1840 . Winnipeg: University of Manitoba Press.

USHER, P.J. 1986. The devolution of wildlife management and the prospects for wildlife conservation in the Northwest Territories. CARC Policy Paper 3. Ottawa: Canadian Arctic Resources Committee.

. 1987. Indigenous management systems and the conservation of wildlife in the Canadian North. Alternatives 14(1):3-9.

WEEDEN, R.B. 1985. Northern people, northern resources, and the dynamics of carrying capacity. Arctic 38(2):116-120.

- 1989. An exchange of sacred gifts. Thoughts toward sustainable development. Alternatives 16(1):42-49.

1992. Messages from the Earth. Fairbanks: University of Alaska Press. 
WENZEL, G. 1991. Animal rights, human rights: Ecology, economy and ideology in the Canadian Arctic. London: Belhaven Press.

WOLFE, R.J., and ELLANNA, L. 1983. Resource use and socioeconomic systems: Case studies of fishing and hunting in Alaskan communities. Juneau: Alaska Department of Fish and Game, Division of Subsistence. 274 p.
WORLD COMMISSION ON ENVIRONMENT AND DEVELOPMENT. 1987. Our common future: The report of the World Commission on Environment and Development. Oxford: Oxford University Press. 